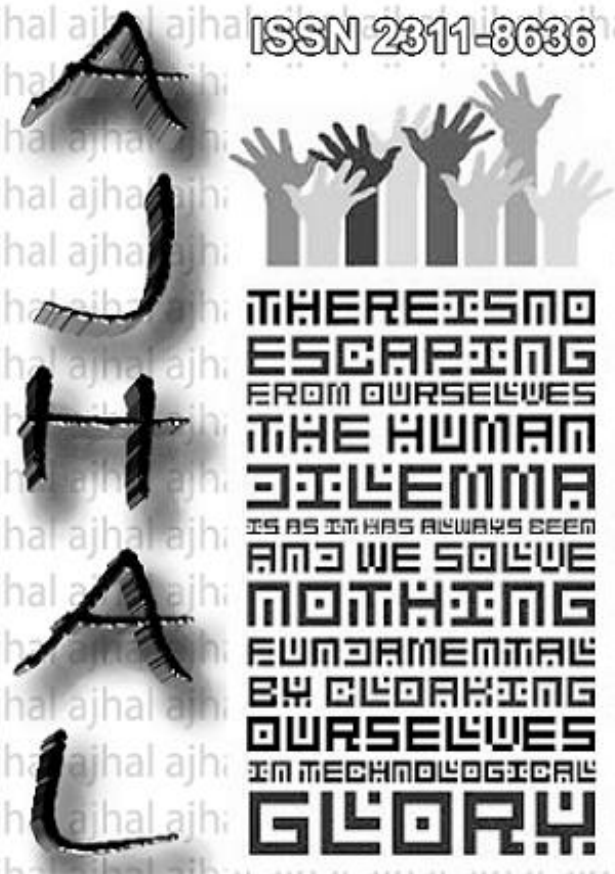

Vol 3, No. 2/2016

Asjan Jourmal of Humanity, Art and Litergatulue 


\section{Physical Abuse, Neglect and Academic Achievement of Primary School Pupils}

\section{O. Ezenwaji Ifeyinwa*, Okwun Ethel Ncheta}

ISSN: 2311-8636 (Print)

ISSN: 2312-2021 (Online)

DOI prefix: 10.18034/ajhal

Licensed:

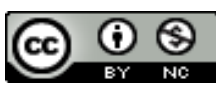

Source of Support: Nil

Conflict of Interest: None Declared

*Email for correspondence:

Ifeyinwa.ezenwaji@unn.edu.ng

Department of Educational Foundations, University of Nigeria, Nsukka-410001, NIGERIA

\section{ABSTRACT}

The study focused on child abuse and neglect on pupils' academic achievement in primary schools. The ex-post facto design was adopted. Out of the four forms of child abuse, two were identified for the study, physical abuse and neglect. Four research questions were formulated to guide the study. The population of the study consist of 3125 primary five (5) pupils. 312 primary five (5) pupils were selected as sample from thirteen primary schools from the population using simple random sampling technique. Mean and standard deviation were used to answer the research questions. The result revealed that physical abuse and child neglect influence pupils' academic achievement. Based on the findings, it was recommended that parents and guardians should see beating, hitting, slapping, punching among others as physical abuse and should desist from using them as means of correcting children under their care. Rather advice and state the implication of any negative behaviour a child wears to correcting them whenever they derail from adult expectations on such children and also make home a peaceful place for their children, love, protect and care for them. The study concluded that if child abuse and neglect are reduced to its beeriest minimum, pupils' academic achievement in primary schools would be enhanced towards development of other levels of education for national development.

Key Words: Child Abuse, Neglect, Physical Abuse, Gender, Academic Achievement, Primary School

\section{BACKGROUND OF THE STUDY}

Every nation all over the World requires education, because education is a necessary tool for personal and national development. It brings about uniformity in the development of children. Education is seen as process of acculturation through which the individual is helped to attain the development of his potentialities, and thereby achieve self-fulfilment (Akubue and Okolo, 2008). Education is also a process whereby every member of a society puts his/her efforts into the all-round development of the child (Ukhurebor and Nnajieto, 2005). It is generally seen as an agent of socialization and integration of a child or an adult into the norms of the society. In order to ensure the growth and development of a nation, it becomes imperative for the right policies to be in place to allow for effective planning 
and execution of educational programmes (Adejobi, Osonwa, Iyam, Udonwa \& Osonwa, 2013). This effective planning and execution can only be properly done if it starts at the foundation of education which is primary education. This suggests that for national development to be enhanced, there is every need for primary education policies and programmes to be well implemented to affect every child in the society.

A child is a person under the age of 18 years, excluding a person who is or has been married (Children First: National Guidance for Protection and Welfare of Children (CFNGPWC, 2011). Department of Children and Families (2013) defined child as any person under 21 years of age. It stresses that a person responsible for a child's care include the child's parents, guardians, foster parents, an employee of a public or private residential home, agency or institution or other person legally responsible under state law for the child. The mother and the child are specially provided for and the child is seen not as belonging to the parents alone but to the entire community. As such the child is showered with love and provided with lots of stimulation from everyone around (Ngwoke \& Eze, 2010). The way the child is handled can affect the child positively or negatively in the society. If children are not well taken care of, the idea of child abuse arises.

The term child abuse is anything which individuals and institutions do or fail to do which directly or indirectly harm children or damage their prospects of safe and health development into adulthood (Wambui, 2000). Olaitan and Akpan (2003) noted that child abuse is the physical or mental injury done to a child which may include beating accompanied by the physical harm done to the child who has no control of his own. Child abuse can also be defined as any act of misuse of a child in any form, such as physical and mental torture (Adeniyi, 2010). Child abuse also involves a situation where a child is maltreated physically, sexually or emotionally and this is detrimental to the future growth and development of such a child. It has been described as any act of maltreatment or subjection that endangers a child's physical, emotional and health development (Hopper, 2004). Royal Canadian Police (2006) affirmed that child abuse is any form of physical, psychological, social, emotional or sexual maltreatment of a child whereby the survival, safety, self-esteem, growth and development of the child are endangered. Child abuse includes any behaviour which neglects the child's survival and development needs and causes physical or emotional injury, harassment and subjects the child to measures, situations and experiences which interfere with the healthy development towards adulthood. Therefore, child abuse is any negative act that can hinders a child self esteem, confidence and health development such as neglect and physical abuse.

Child abuse as a concept is very wide and vast, it has types and classifications. The World Health Organization (WHO, 2006) classified child abuse into four forms: Physical abuse, sexual abuse, emotional or psychological abuse and neglect. Oniyama and Asamaigbo in Apebende, Umoren, Ukpepi and Ndifon (2010) say that child abuse manifests in four main categories; physical abuse, sexual abuse, emotional abuse and neglect. Specifically, this study is anchored on two common forms of child abuse; these are physical abuse and child neglect. United State Department of Health and Human Services (U.S. DHHS, 2010) states that physical abuse constitutes 71 percent of all abuses while neglect constitutes 16.1 percent. According to the Child Welfare Information Gateway (CWIG, 2008), children are more likely to be the victims of neglect than any other type of abuse it stresses that in 2008, $73.3 \%$ of all child abuse victims were victims of neglect. Neglect represented $16.1 \%$ of all victims, sexual abuse $9.1 \%$ of all victims and emotional abuse $7.3 \%$ of all victims. The remaining $4.2 \%$ of child victims experienced other types of maltreatment such as abandonment, threat and drug exposure. Due to these alarming numbers, there is a great numbers of the researchers trying to investigate the influence of physical abuse and neglect on pupils academic achievement. 
Physical abuse refers to any contact with the body of the child, which may result in an injury. Such contact may involve beating, hitting, kicking, shaking, punching or any act or omission that is not an accident but that which brings some injuries to the child's body. A child is physically abused if he/she is beaten up too often, over-used in the home, on the farm or in the factory (Ushie, David, and Ifere, 2011). Physical abuse is also seen as any physical injury inflicted other than by accidental means, any injury at variance with the history given of them or a child's condition which is the result of maltreatment such as malnutrition, deprivation of basic need or cruel punishment. Examples of injuries which may result from physical abuse include: head injuries, bruises, cuts, and internal injuries and death (Department of Children and Families, (2013). In the Children First-National Guidance for the Protection and Welfare of Children (CF-NGPWC, 2011), physical abuse of a child is that which results in actual or potential physical harm from an interaction, or lack of interaction, which is reasonably within the control of a parent or person in a position of responsibility, power or trust. Physical abuse can involve severe physical punishment, slapping, pushing, pinching, biting, choking or hair-pulling, terrorizing with threats and observing violence. Based on the above views, physical abuse is any physical injury inflicted on the body of a child whether intentional or unintentional which can cause damage on the child's development.

Several studies have shown that physically abused children have poorer school performance and lower educational achievement than non-abused pupils. Physical abuse also has longlasting effects on mental health, social isolation, criminal behaviour, drug and alcohol misuse, risky sexual behaviour and even obesity, which persist into adulthood (Ba-Saddik and Hattab, 2013). Physical abuse of children leads to aggressive behaviour, emotional and behavioural problems and educational difficulties in children (Finkelhor, 2008).

Neglect is a deliberate action of a parent or close relation purposely to inhibit the child from obtaining essential needs for a normal life, which may include food, shelter, clothing, education and protection from danger (Olatian and Akpan, 2003). West Africa Certificate (2003) sees neglect as when a child is abandoned to its fate either by its parents, guardian or the society at large. National society for the prevention of Cruelty to Children (NSPCC, 2010) asserts that neglect can occur while the baby is still inside her mother's womb as may be the case with maternal substance abuse.

Department for Children and Families (DCF, 2013) postulated that neglect is when children do not receive adequate food or shelter, medical treatment, supervision, care or nurturance to such an extent that their development is damaged or injured. Some examples are leaving a child alone without appropriate supervision, not ensuring that the child attends school or not enrolling the child at school having infection because of poor hygiene or lack of medication, not giving a child affection or emotional support not getting medical help when required. DCF (2013) classified neglect into physical neglect, medical neglect, educational neglect, emotional neglect and moral neglect. They explain that physical neglect includes failure to provide adequate food, shelter and clothing appropriate to the climate and environmental conditions, while medical neglect is failure to provide, whether intentional or otherwise medical care leaving a child alone for an excessive period of time, withholding medical treatment from infants especially those with life-threatening conditions. On the other hand, educational neglect occurs when a child aged seven years old through fifteen (15) years old is not registered in school. Emotional neglect and moral neglect is the denial of proper care and attention to the child.

Neglect, according to Okpara (2001) includes inadequate feeding, shelter and lack of supervision, inadequate body care, poor clothing, denial of medial attention and inadequate provision of educational materials and supervision. Other aspects of neglect may include 
letting the child live in a filthy environment and non provision of proper nourishment. Other aspects of child abuse may include child exploitation, slavery, trafficking and abandonment. The National Clearinghouse on Child Abuse and Neglect Information (NCCANI, 2001) noted also that neglect can be physical, educational, or emotional. Physical neglect according NCCANI includes refusal of or delay in seeking health care, abandonment, expulsion from the home or refusal to allow a runaway to return home and inadequate supervision. Educational neglect includes the allowance of chronic truancy, failure to enrol a child of mandatory school age in school and failure to attend to a special educational need. Emotional neglect includes such action as inattention to the child's needs for affection, refusal of or failure to provide needed psychological care, and permission of drug or alcohol use by the child.

Educational neglect has so many negative influences on the academic achievement of an abused child. The United States National Survey of Child and Adolescent Well Being (U.S NSCAWB, 2003) found out that children placed in out-of-home care due to child abuse tended to score lower than the general population in measures of cognitive capacity, language development and academic achievement. Mills (2004) opined that abused children perform poorly on standardized tests and achieve poorer school marks. An abused child may also not feel free among others he or she may exhibit aggressive tendency, language skill problems (The Canadian Centre for Justice Statistics (CCJS, 2001). Children who experience neglect or rejection are more likely to develop antisocial traits as they grow up and are more associated with borderline personality disorders and violent behaviour (Schore, 2003). Research by Sidebotham (2007) suggests that up to 40 percent of maltreatment-related deaths is probably the result of neglect or a combination of neglect and other forms of abuse, with death resulting from extreme malnutrition, electrolyte imbalance, hypothermia or infection. Many fatal cases seem to have an element of intent to deprive the child of his or her needs. Sidebotham went further to affirm that persistent neglect can lead to serious impairment of health and development and long-term difficulties with social functioning, relationships and educational progress. In extreme cases, neglect can also result in death.

Many studies on causes of poor academic achievement have consistently stressed that abused and neglected children, on the average, score lower on cognitive measure and demonstrate lower school achievement when compared with non abused peers. Neglected children are the last successful on cognitive tasks in class compared with the other types of abused children. They are also inattentive and apathetic and they have difficulty in concentrating on cognitive tasks. (Adejobi, et al, 2013) Gaudin (1999) maintained that neglected children have the worst delay in language comprehension and expression while the psychological neglected children score lower in intelligence quotient tests. Furthermore, children who are experiencing parental neglect would also exhibit low self esteem, have poor social relationships, frequent lateness or non attendance to school, poor personal hygiene, have constant hunger, inappropriate clothing, untreated medical problems, constant tiredness and compulsive stealing or scrounging (Wambui, 2000). It can be categorically stated that children who under go all forms of abuse may involve themselves in mischievous act, feel inferior, lack concentration and interest, exhibit delinquent behaviour, passive during instruction, sleep in the class during lesson, not regular in the school and eventually drop out of school. All these types of behaviour could influence pupils' academic achievement in school.

Neglected children are more likely to suffer from a serious physical injury due to an accident such as falling, drowning, fire or ingesting poison. Hildvard and Wolfe, (2002) are of the view that individuals who suffer from neglect in early childhood, more often shown academic and cognitive deficits, social withdrawal and more internalization of problems. 
For the above vices to be checked or eradicated, recognizing and reporting child abuse are important to prevent them from continuing or recurring (Child Welfare Information Gateway (CWIG, 2008). They went on to stipulate that schools are in a unique position to address this problem by virtue of the staff's training and expertise, the school's position in the community and the availability of physical facilities. A school's involvement in preventing child abuse can be divided into school based programs, school based community programs and individual action on the part of educators. Olaitan and Akpan (2003) claim that moderate approaches could be utilized to minimize child abuse in societies where they occur. These approaches include counselling of parents, assisting parents in child care activities, legislation against child abuse and carrying out more research work and funding of studies on child abuse.

The researcher has observed that in Nigeria male and female children, especially between 6 to 16 years are often seen along the street hawking goods such as oranges, bananas, groundnuts and sachet water, among others for their parents/guardians. Many others are also seen along the street begging for money when they should be in school laying solid foundation for their future. Some children are physically abused; kicked, beaten, burned, thrown against walls, hitting, suffocated and punched. Some are humiliated and terrorized by the people who are supposed to take care of them. Some parents abandon their children at home in search of livelihood leaving them in the hands of caregivers. Some parents abuse their children by using them in their farm work, trade and businesses and do not bother to look into how the children are faring in school. They rather invest much of their time in personal and business pursuits while the children's academics suffer and in most cases the children drop out of school (Ebosele, 2000). It has been observed that some schools as well as some parents fail to provide supervision and safety for children under their care. The teachers, especially where there are large numbers of pupils, do not have time to go round and supervise the children during class work (Gaudin, 1999). In addition, some parents equally do not provide basic necessities of life for their children, leaving them at the mercy of the society and these children of school age are out of school and little or with no future (Adeniyi, 2010). Bosede (2010) affirmed that there are cases of dirty and tattered uniformed, students stealing or begging for food, students not coming to school regularly and students sleeping during lesson almost all the time. Some of them are affected with anxiety, depression and passive behaviour. Some of the students manifest aggressive and disruptive behaviours, inappropriate acts or delinquent behaviours. Some seek inappropriate affection from other students. All these types of negative behaviours could influence pupils' academic achievement.

Achievement is the level of performance attained by a learner in a particular task (Karma, 2009). Akinteye (2008) considers achievement as a task that somebody has carried out successfully, especially using his effort and skills. So, achievement is excellence in all academic disciplines, in class as well as co-curricular activities. It includes excellence in sporting behaviour, confidence, communication skills, punctuality, arts, culture and the like which can be achieved only when an individual is well adjusted. Academic achievement is defined as the knowledge obtained or skills developed in the school subjects usually designed by test scores or marks assigned by the teacher (Ganai and Ashraf, 2013). It indicates the learning outcome of the students. Browsard (2002) defined academic achievement as the overall academic performance of students in the school. It is assessed by the use of teachers' rating test and examination. United State Department of Health and Services Centers for Disease Control and Prevention (US. DHSCDCP, 2010) postulated that academic achievement includes standardized test scores in subject areas such as reading, mathematics and language arts; Grade Point Average (s); classroom test scores and other formal assessments. Thus, academic achievement deals with what a learner is able to accomplish by execution of class work in the school. It enables a learner to know the extent he or she has attend the criterion performance in the school. 
Eze (2009) described achievement as something which has been accomplished successfully, especially by means of exertion, skill, practice or perseverance. Achieving result in academics have many functions which include: to enable us determine the relative position or rank of individual student with respect to their performance. It also enables us to obtain information on the extent to which a student has attained the criterion performance. It achievement could be seen as a product of series of effort obtained by a student.

Children who are abused also receive lower ratings of performance from their school teachers; score lower on cognitive assessments and standardized tests of academic achievement, obtain lower grades and get suspended from school and retained in grade more frequently (Rowe and Eckenrode, 1999; Shonk and Cicchetti, 2001). Abused children are also prone to difficulty in forming new relationships with peers and adults and in adapting to norms of social behaviour (Toth and Cicchetti, 1996). Academic achievement is the outcome of education, the extent to which a learner has achieved his or her educational goals.

Academic achievement of pupils in primary schools may vary significantly by gender. Gender as a sociological term, refers to the role and attributes or behaviour that society has assigned to the two sexes (Azikiwe, 2006). It also could be seen as a form of social differentiation. It refers to a socio-cultural distinction between males and females (Akubue and Okolo, 2008). According to Johnson (2000) girls perform better in reading and writing subjects while boys perform better in the more analytical subjects such as mathematics and sciences. Assert that many authors have expounded on this idea, yet the data on the male and female achievement gap are often inconsistent. The same author opines that, in 1998 male pupils scored higher on both the verbal and quantitative sections of the Achievement Test (AT) than female pupils. It has been noted that this may be because of a fundamental bias against females in educational system. This could be as a result of different kinds of child abuse experienced by the females.

\section{THEORETICAL FRAMEWORK}

Maslow's Hierarchy of Needs (1943). Maslow postulated that human needs are many and varied. At any instant, individuals are confronted with many needs seeking for attention.

Physiological needs include primary needs such as food, water, shelter, sex, rest and sleep. If these needs are not met, the human body simply cannot continue to function. Considering the need for sleep and food further, it is easy to see areas of this stage that can seriously affect how a child performs in school. Without a proper diet and reasonable amount of sleep, children's concentration will decline and their minds will be focused on other things such as hunger. The implication is that children will lack the energy required to actively participate in activities throughout the school day and this could affect their performance in the classroom. Safety needs include the need for security, dependency, structure, freedom from fear and long-term stability. If the classroom is a fearful, unpredictable place and students seldom know where they stand, they are likely to be more concerned with security than with leaning. Children require protection but child that is under pressure of being abuse is likely to experience insecurity.

Maslow theory is basically of the opinions of meeting human needs in a hierarchical order of importance from physiological needs to needs for self actualization, it is important to understand that all children have a set of needs that if met, with the help of parents, friends and teachers can help mould a child and build a good foundation for adulthood and for better academic achievement. If there is a deficiency in the needs or any is neglected, it can result in hindering a child's performance and behaviour in school. Again, a child that is well fed and protected will pay attention in the class and this will result in better academic achievement. 


\section{REVIEW OF EMPIRICAL STUdies}

Several researches have been carried out be scholars and professionals on the issues of child abuse. Ugwu (2007) carried out research on the forms of Child Abuse and Neglect in primary schools in Nsukka Education Zone four research questions, four purpose of study and a hypothesis guided the study. The design for the study was descriptive survey research. The multistage sampling technique was used to select 15 schools ( 5 from each of the 3 Local Government Education Authorities. Second stage, simple random sampling technique was used (balloting with replacement) to select 300 teachers (20 from each of the 15 selected schools). The same simple random technique was used to select 300 students (20 pupils from each of the 15 selected schools). Face to face administration of the instrument was adopted. The method used in analyzing the data was mean and standard deviation while t-test was used to analyze the hypothesis. The research identified physical abuse, sexual abuse, psychological abuse and child neglect as forms of child abuse and neglect.

The similarity between the reviewed work and the present study is that, the reviewed work is on the forms of child abuse and neglect while the current study is on the influence of child abuse on pupils' academic achievement. However, there are remarkable differences between the reviewed work and the current study. The reviewed work adopted descriptive survey design while the current study adopted ex-post-facto research design. Again, the reviewed work was conducted in Ebonyi State where the present study was done.

Adejobi, Osonwa, Iyam, Udonwa and Osonwa (2013) carried out a research on child maltreatment and academic performance of senior secondary school students in Ibadan, Nigeria. This research was carried out to examine the effect of child maltreatment and academic performance of senior secondary school students in Ibadan, Nigeria. This research was carried out to examine the effect of child maltreatment on academic performance of senior secondary school students. The design was descriptive research design. Simple random sampling technique was used for the study. The questionnaire was the instrument of data collection, administered to five hundred and twelve students selected randomly in two local government areas. A hypothesis was formulated to guide the study. The data was analyzed using simple percentage and multiple regression analysis. The result indicated that there is significant relationship between child maltreatment and academic performance.

The similarity between the reviewed work and the current study is that the reviewed work is on child maltreatment and academic performance while this current study is on influence of child abuse and neglect on pupils' academic achievement.

Ibiam (2005) conducted a study on the incidence of Child abuse on primary school children in Abakaliki Urban. Ibiam made use of 210 members of staff of the welfare unit and 20 police officers concerned with juvenile welfare services. The researcher had three purposes of study and three research questions. The design for the study was descriptive design. The method used in analyzing the data was mean and standard deviation and $\mathrm{t}$ test statistics. The researcher identified physical abuse, sexual abuse, child neglect, child abandonment and child labour as forms of child abuse discovered that while boys were more physically abused, girls were more sexually abused.

The similarity between the reviewed work and the current study is that, the reviewed work geared to identify the incidence of child abuse on primary school children while the current study is on the influence of child abuse on pupils' academic achievement. However, there are great different between the reviewed work and the current study. The reviewed work adopted descriptive design while the present study adopted ex-post facto research design. 
Ezenwa (2009) conducted a study on the influence of child labour and parental support on children's interest in school attendance and achievement motivation among primary school pupils in Nsukka. Six research questions and six hypotheses guided the study. The design of the study was ex-post facto research design. The sample for the study consisted of three and thirty one (331) primary five pupils, 171 boys and 160 girls in government schools in Nsukka Urban Education Zones. The major instrument for collection of data was questionnaire. The data collected were analyzed using mean and standard deviation and t-test statistical tools. The results revealed that pupils' interest in school attendance is significantly influenced by child labour. The reviewed study is related to the present study because child labour is part of child abuse which is the concern of the present study.

However, most parents love and nurture their children yet some cannot take proper care of their children by not meeting up with the children's basic needs. Some parents neglect their children by not meeting up with children's basic needs. Some parents engage their children in struggle for survival without providing food, appropriate clothing, enough medical care, education and necessary materials needed in the school for their children. Some children suffer hunger because they are not given enough food while some are left with wounds all over their body without proper treatment and care. Child abuse is destructive to the child who experiences it. Some caregivers beat children to death with the slightest provocation while some children are humiliated and terrorized by the people who are supposed to take care of them. These evidences of child abuse could affect negatively the psyche of the child as a learner in primary school which may influence the academic achievement. Ba-Saddik and Hattab, (2013) noted that physically abused children have long-lasting effects of mental health, social isolation, criminal behaviour, drug and alcohol misuse, risky sexual behaviour and even obesity, which persist into adulthood. From literature reviewed, child abuse is a social problem that has rooted deeply in different societies today. It has assumed a complex dimension in the $21^{\text {st }}$ century ranging from physical abuse to child neglect.

Thus, the problem of the study is to investigate the influence of child abuse on pupils' academic achievement in primary schools. The researchers therefore seek to find out: the influence of physical abuse and neglect on pupil's academic achievement.

\section{Purpose OF THE StUdy}

The main purpose of the study is to find out the influence of child abuse on pupils' academic achievement in primary schools. Specifically, the study seeks to:

- Investigate the influence of physical abuse on pupils' academic achievement in primary schools.

- $\quad$ Find out the influence of child neglect on pupils' academic achievement in primary schools.

- Determine the influence of physical abuse on male and female pupils' academic achievement.

- Determine the influence of child neglect on male and female pupils' academic achievement.

\section{RESEARCH Questions}

The following research questions guided the study:

- What is the influence of physical abuse on pupils' academic achievement in primary schools?

- What is the influence of child neglect on pupils' academic achievement in primary schools?

- What is the influence of physical abuse on pupils' academic achievements based on gender?

- What is the influence of child neglect on pupils' academic achievement based on gender? 


\section{HYPOTHESES}

The following hypotheses guided the study and were tested at 0.05 level of significance:

H01: There is no significant influence of physical abuse on pupils' academic achievements based on gender

H02: There is no significant influence of child neglect on pupils' academic achievements based on gender.

\section{Research Method}

The design for this study is ex-post facto research design. According to Nworgu (2006) ex-post facto design is a type of design in which data are collected after the event or phenomenon under investigation has taken place and for which the researcher does not have control over the variables he or she is interested in and cannot manipulate them. Ex-post facto design appears appropriate for this study because, the topic of study, influence of child abuse on pupils' academic achievement cannot be manipulated by the researchers as the pupils are made to provide information on their experiences on physical abuse and child neglect.

The area of study is Afikpo North Local Government Area. Afikpo North Local Government Area is one of the 13 Local Government Areas in Ebonyi State. It has 66 public primary schools settled within the area. Afikpo is one of the Igbo groups Located in the South Eastern part of present day Nigeria. Afikpo North Local Government Area is a hilly region that lies in a sensational rain zone between sea grass land and tropical rain forest with an average annual rainfall, each of the villages is naturally demarcated by stream which forms natural boundaries. Their major occupation is farming and trading. However, there are those who are either teachers or civil servants. The researchers chose this area because observation has shows that some parents abuse their children by beaten them mercilessly with the slightest provocation while some parents abandon their children at home without appropriate supervision on their children's education, enough medical care, and necessary materials needed in the school for their children. Others use their children mostly in their farms, exposing the children as slave labourers.

The population of this study consists of 3125 primary five (5) pupils in all the 66 public primary schools in Afikpo North Local Government Area. These are made up of boys and girls. This group is chosen because children in primary five (within the ages of 10 and 12 years) can be easily guided to supply the information needed for the investigation. (Source: Local Government Education Authority, Afikpo North Local Government Area, Ebonyi State).

The sample for this study is three hundred and twelve (312) primary five pupils in Afikpo North Local Government Area. Simple random sampling technique was used to select 13 primary schools from the 66 public primary schools in the area. Out of the 13 primary schools, 24 pupils were selected from primary five (5) in each class (12 males and 12 females) using simple random sampling technique thereby making a total of three hundred and twelve (312). The reason for using simple random sampling is to give every research subject equal chance of being selected for the study.

The instrument used for data collection was structured questionnaire. The questionnaire was developed by the researchers and was titled: child abuse on pupils' academic achievement questionnaire (CAPAAQ). The instrument is made up of twenty (20) items on influence of physical abuse and child neglect. The questionnaire was divided into two clusters. Clusters " $\mathrm{A}$ " and " $\mathrm{B}$ " Cluster " $\mathrm{A}$ " was structured to elicit information on the influence of physical abuse on pupils' academic achievement and it consists of eight (8) items. In cluster " $\mathrm{B}$ ", items were structured to seek information on the influence of child neglect on pupils' academic achievement and it has twelve (12) items. Four-point rating 
scale of, Strongly Agree (SA = 4), Agree (A = 3), Disagree (D =2) and Strongly Disagree $(\mathrm{SD}=1)$ was used to elicit pupils responses. Mean rating of 2.5 and above was considered as acceptable while mean rating below 2.5 was considered unacceptable.

In addition, annual report of the pupils was used to determine the achievement scores of the pupils. The data was interpreted using mean and standard deviation. Mean was used to find out the average achievement of the pupil in the study area using their first, second and third term results. The grand mean score between 0-49 was taken as low achievement while the grand mean score between 50-100 was taken as high achievement. The instrument was face validated by three experts, two in the Department of Educational Foundations (Educational Psychology and Sociology of Education) and one in Department of Science Education (Measurement and Evaluation); all from Faculty of Education, University of Nigeria, Nsukka. They were requested to look through the instrument and ascertain its appropriateness for the study bearing in mind the purpose of the study, research questions and hypotheses. After examining the instrument, the corrections and suggestions made guided the present instrument.

A trial test was carried out to ascertain the reliability of the instrument. The instruments were trial tested after validation. The copies of the questionnaire were administered on twenty pupils in Central Urban Primary School 1, Ebonyi Local Government Area, which is not part of the study area. The data collected were analyzed using the Cronbach's Alpha Reliability Technique. The following reliability coefficients were obtained as follows 0.74 and 0.66 for influence of physical abuse and influence of neglect on pupils' respectively. These results showed that the instruments are reliable. Face to face administration of the instrument was adopted. This means that the researchers personally with the help of two research assistants administered the questionnaire to the pupils. This was to avoid loss of some of the instruments and minimize time waste. The instruments were collected immediately after completion. In addition, annual report of the pupils was collected to determine the influence of child abuse on pupils' academic achievement.

The data collected was analyzed using mean and standard deviation to answer the research questions. Mean value of 2.50 and above was the benchmark for acceptance while any mean value below 2.50 was rejected. The t-test statistic was used to test the stated hypotheses at 0.05 alpha levels to determine the significance of the mean difference. Also, mean and standard deviation were used to find out the average academic achievement of the pupils in the study area using their first, second and third term results. The decision rule, the mean score above 50 was termed good academic achievement while the mean score below 50 was termed poor or low academic achievement.

\section{Results ANd Discussions}

\begin{tabular}{|l|l|l|l|l|l|}
\hline S/N & Item Statement & $\mathbf{N}$ & Mean & Std Deviation & Decision \\
\hline 1 & I am always beaten up by my parents/guardians & 312 & 3.29 & .87 & Accept \\
2 & My parents do slap me & 312 & 2.77 & 1.01 & Accept \\
3 & I do too much domestic work every day before & 312 & 2.92 & .93 & Accept \\
& going to school & & & & \\
4 & My parents/caregivers always knock on my head & 312 & 3.00 & .70 & Accept \\
5 & My parents/guardians never used to hit me & 312 & 3.04 & 1.14 & Accept \\
6 & I hate going to school because my teacher always & 312 & 2.90 & .99 & Accept \\
& twist my ears & & & & \\
7 & The family I live with beat me until injury occurs & 312 & 2.80 & 1.09 & Accept \\
8 & My parents/guardians always punched at my back & 312 & 3.04 & .92 & Accept \\
& Overall Mean & 312 & 2.97 & .47 & Accept \\
\hline
\end{tabular}


Table 1 shows the mean and standard deviation of the responses of pupils with respect to the influence of physical abuse on their academic achievement. The analysis shows that items 1 to 8 had mean responses of; 3.29, 2.77, 2.92, 3.00, 3.04, 2.90, 2.80, and 3.04 with an overall mean responses of 2.97. This implies that physical abuse has influence on the pupils' academic achievement since all the items had mean responses greater than the 2.50 bench mark mean.

Research Question two: What is the influence of child neglect on pupils' academic achievement in primary schools?

Table 2: Mean and Standard deviation of responses of pupils' on the influence of child neglect on their academic achievement.

\begin{tabular}{|l|l|l|l|l|l|}
\hline S/N & \multicolumn{1}{|c|}{ Item Statement } & N & Mean & Std Deviation & Decision \\
\hline 9 & My parent/guardians do not love me & 312 & 3.11 & .85 & Accept \\
\hline 10 & I go to school with my lunch & 312 & 2.82 & 1.09 & Accept \\
\hline 11 & I do not eat before going to school & 312 & 2.90 & 1.02 & Accept \\
\hline 12 & $\begin{array}{l}\text { If I am prevented to participate in class activities, } \\
\text { I feel rejected }\end{array}$ & 312 & 3.40 & .80 & Accept \\
\hline 13 & I go to school with torn school uniform & 312 & 2.80 & 1.09 & Accept \\
\hline 14 & $\begin{array}{l}\text { My parents/guardians do not check my } \\
\text { assignments and that makes me to lack interest in } \\
\text { school }\end{array}$ & 312 & 3.48 & .82 & Accept \\
\hline 15 & $\begin{array}{l}\text { I don't attend school regularly because my } \\
\text { parents/guardians do not border whether I go to } \\
\text { school or not }\end{array}$ & 312 & 3.46 & .85 & Accept \\
\hline 16 & $\begin{array}{l}\text { I feel inferior in the class because my parents do } \\
\text { not care about my needs }\end{array}$ & 312 & 2.80 & .95 & Accept \\
\hline 17 & $\begin{array}{l}\text { I fail in most of my school examinations because } \\
\text { nobody care about the results }\end{array}$ & 312 & 3.00 & .97 & Accept \\
\hline 18 & $\begin{array}{l}\text { Whenever I go to school with sickness, I do not } \\
\text { pay attention during lessons and school activities }\end{array}$ & 312 & 3.60 & .78 & Accept \\
\hline 19 & $\begin{array}{l}\text { My parents/guardians do not treat me when I } \\
\text { am sick }\end{array}$ & 312 & 2.55 & .92 & Accept \\
\hline 20 & My parents provide me with all I need in school & 312 & 2.35 & 1.06 & Reject \\
\hline & Overall Mean & 312 & 3.02 & .32 & Accept \\
\hline
\end{tabular}

Analysis of data in table 2 shows that that items 9 to 20 had mean responses of 3.11, 2.82, $2.90,3.40,2.80,3.48,3.46,2.80,3.00,3.60,2.55$ and 2.35 while the overall mean response is 3.02. The analysis implies that all the items had mean responses more than the 2.50 bench mark mean for decision taking. Hence, child neglect influences pupils' academic achievement. However, item 20 with the mean of 2.35 is below the bench mark mean for decision taking. It means that parents do not provide their children with all they need. This suggests that parents neglect the need of the pupils.

Research Question three: What is the influence of physical abuse on pupils' academic achievement in primary schools based on gender?

Table 3: Mean and Standard deviation of male and female pupils' academic achievement

\begin{tabular}{|l|l|l|l|}
\hline Gender & N & Mean & Std Deviation \\
\hline Male & 156 & 63.21 & 10.07 \\
\hline Female & 156 & 54.26 & 15.14 \\
\hline
\end{tabular}


Table 3 shows the mean achievement scores of male and female pupils as influenced by physical abuse. Male pupils had mean achievement score of 63.21 with a standard deviation of 10.07 while female students had mean achievement score of 54.26 with a standard deviation of 15.14. This shows that the influence of physical abuse on pupils' achievement may be high on the female pupils.

Research Question four: What is the influence of child neglect on pupils' academic achievement in primary schools based on gender?

Table 4: Mean and standard deviation of male and female pupils' academic achievement

\begin{tabular}{|l|l|l|l|}
\hline Gender & N & Mean & Std Deviation \\
\hline Male & 156 & 52.47 & 13.91 \\
\hline Female & 156 & 53.05 & 14.16 \\
\hline
\end{tabular}

Table 4 shows that the mean achievement score of male pupils as influenced by child neglect is 52.47 with a standard deviation of 13.91 while female pupils had mean achievement score of 53.05 and a standard deviation of 14.16. This implies that the mean achievement score of female pupils is slightly higher than those of their male counterparts. Hence, the academic achievement of male pupils is being influenced more by child neglect.

Hypothesis One: There is no significant influence of physical abuse on pupils' academic achievement based on gender.

Table 5: t-test analysis of the influence of physical abuse on pupils' academic achievement in primary schools based on gender

\begin{tabular}{|l|l|l|l|l|l|l|}
\hline Gender & Number & Mean & Std Deviation & Df & t-cal & Sig. (2-tailed) \\
\hline Male & 156 & 63.21 & 10.07 & & & \\
\hline Female & 156 & 54.26 & 15.14 & 310 & 6.140 & .000 \\
\hline
\end{tabular}

The analysis data in table 5 shows that the probability associated with the calculated value of $t$ (6.140) for the influence of physical abuse on pupils' achievement is .000. Since the probability value of .000 is less than the 0.05 level of significance, the null hypothesis was rejected. Hence, there is a significant influence of physical abuse on pupils' academic achievement based on gender in favour of the male pupils.

Hypothesis two: There is no significant influence of child neglect on pupils' academic achievement based on gender.

Table 6: t-test analysis of the influence of child neglect on pupils' academic achievement in primary schools based on gender

\begin{tabular}{|l|l|l|l|l|l|l|}
\hline Gender & Number & Mean & Std Deviation & Df & t-cal & Sig. (2-tailed) \\
\hline Male & 156 & 52.4722 & 13.91681 & & & \\
\hline Female & 156 & 53.1013 & 14.16984 & 310 & -.357 & .722 \\
\hline
\end{tabular}

Table 6 shows that the probability associated with the calculated value of $t(-.357)$ for the influence of child neglect on pupils achievement is .722. Since the probability value is greater than 0.05 level of significance, the null hypothesis was accepted meaning that there is no significant influence of child neglect on pupils' academic achievement based on gender. 


\section{Discussion OF RESULTS}

The findings revealed that physical abuse has influence on pupils' academic achievement. Such abuses include beating slapping, giving a child too much domestic work, hitting and punching. This is in accordance with B-saddik and Hattab (2013) that maintained that physically abused children have poorer school performance and lower educational achievement than non-abused children. This is in line with Adejobi, Osonwa, Iyam, Udonwa and Osonwa (2013) that asserted that physically abused children score lower on cognitive measures and demonstrate lower school achievement when compared with non abused peers. This is because they are always inattentive and apathetic and they had difficulty in concentrating on cognitive tasks. However, when a child is often beaten, over-used at home or in the farm, it will be difficult for such a child to concentrate and pay attention in the class. An over-used child usually suffer from fatigue and unable to stand academic challenges.

There is the indication that physical abuse has a significant influence on pupils' academic achievements of female pupils than those of the male counterparts. It again documents that there is a significant influence of physical abuse on pupils' academic achievement based on gender in favour of the male pupils. For Ba-saddik and Hattab (2013), asserted that male children academic achievement are influence more by physical abuse than those of the female counterparts.

The findings equally showed that child neglect has influence on pupils' academic achievement. Neglect such as failing to show love to a child, not giving a child food before going to school or lunch, not paying attention in a child's education, and lack of attention to a child when he/she is sick. The results conform to the Child and Adolescent Well Being (2003) that documented that children placed in out of home care due to child abuse tended to score lower than the general population in measure of cognitive capacity, language development and academic achievement. Gaudin (1999) maintained that neglected children have the worst delay in language comprehension and expression while the psychological neglected children score lower in intelligence quotient tests. In the observation made by Hildvard and Wolf (2002) individuals who suffered from neglect in early childhood more often show academic and cognitive deficits, social withdrawal. The results in table 4 of chapter four indicated that the mean achievement score of female pupils is slightly higher than those of their male counterparts. The findings revealed that academic achievements of male pupils' were more influenced by child neglect than female counterparts. Finally, there is no significant influence of child neglect on pupils' academic achievement based on gender. This suggests that child neglect has equal influence on pupils' academic achievement. This implies that child neglect is not gender discriminatory as it concern pupils' academic achievement.

\section{Conclusion And Recommendations}

The findings of this study revealed that physical abuse and neglect have influence on the pupils' academic achievement. It also revealed that, there is a significant influence of physical abuse on pupils' academic achievement based on gender in favour of the male pupils while there is no significant influence of child neglect on pupils' academic achievement based on gender.

Based on the findings of the study, the following recommendations were made:

The government should create conducive atmosphere for children's upbringing and initiate programmes aimed at ensuring a meaningful and purposeful future for the pupils in primary schools through elimination of all forms of all forms of physical abuse and neglect. Workshop, seminars and enlightenment programmes should be organized from time to time for parents, guardians, heads of schools, teachers including children to sensitize them 
on the effects and implications of physical abuse and neglect on children. This would help to promote academic achievement in other levels of education for national development since primary education is the foundation of the education system.

All parents should take advantage of the Primary Education and send all their children of school age to school and make sure all the necessary materials are being provided for better academic achievement.

Parents and guardians should see beating, hitting, slapping, punching, among others as physical abuse and not as a way of disciplining children and so should desist from using them as means of correcting children under their care. They should rather use advice and stating the implication of any behaviour a child wears to correcting them whenever they derail from their adult expectations on such children.

Parents should make home a peaceful place for their children, love, protect and care for them. This if done, would promote academic achievement of primary school pupils. Children should be educated on acts and, or actions that constitute child abuse. This would enable them to report to appropriate authority whenever they are abused in any form. This if done would help the pupils to concentrate in their studies without much distraction as a result of child abuse towards enhancing academic achievement of pupils in primary schools for national development.

\section{REFERENCES}

Adejobi, A, O, Osonwa, O, Iyam, M.A, Udonwa, R. E \& Osonwa, R. H. (2013). Child Maltreatment and Academic Performance of Senior Secondary School Students in Ibadan, Nigeria. Journal of Educational and Social Research 3 (2) 175-183.

Adeniyi, E. (2010). Child Abuse: Nigeria is sitting on a Keg of Gun Powder. 2004-2012 African Newspapers of Nigeria, 1-4.

Akinteye, M. K. (2008). Comparative Effect of Mastery Learning and Enhanced Mastery Learning Strategies on Student's Achievement in Mathematics. (Unpublished doctoral dissertation), University of Ibadan, Ibadan.

Akubue, F.N \& Okolo, A.N. (2008). Sociology of Education, Nsukka: Great AP Express.

Apebende, E.U., Umoren, G., Ukepepi, B., Ndifon, R.A. (2010). African Research Review: An International Multi-Disciplinary Journal, 4 (1) 470-478.

Azikiwe, U. (2006). Gender Issues and Education in Nigeria. Implications for Growth \& Development. Paper presented at the $11^{\text {th }}$ Annual International Management Conference Organized by Makerere University Business School, Kampals, Uganda

Ba-Saddik, A.S \& Hattab, A.S. (2013). Physical abuse in Basic-Education Schools in Aden Governorate, Yemen: a cross-sectional study. Eastern Mediterranean Health Journal, 19 (4). 333-339.

Browsard, Z. (2002). Causes of Poor Achievement in WAEC Mathematics Examination in River State Secondary Schools Nigeria. International Journal of Mathematics Education, 21(3).110-120

Canadian Centre for Justice Statistics (CCJS) (2001). Family violence in Canada: A Statistical Profile. Ottawa: Statistics.

Child Welfare Information Gateway (CWIG)(2008). Long Term Consequences of Child Abuse and Neglect. Retrieved April 4, 2013 from http://www.childwelfare.gov/pubs/factsheet/longterm.consequencies.cfm

Department of Children and Families (DCF) (2013). Retrieved 10 February, 2014 from http://www.icfs.gov/home.

Department of Children and Youth Affairs (DCYA) (2011). Children First: National Guidance for the Protection \& Welfare of Children. Dublin: Governmetn.

Ebosele, M. (2000). Still a Cerim future for the African child. The Guardians p. 15

Eze, P. N. (2009). Effects of Peer Assessment on Students Achievement Factors and Interest, An (Unpublished doctoral dissertation) in French, University of Nigeria Nsukka.

Ezenwa, G. M. (2009). Influence of child labour and parental support on children's achievement in school attendance and achievement motivation among primary school pupils in Nsukka. (Unpublished master's thesis), University of Nigeria, Nsukka. 
Federal Republic of Nigeria, (FRN) (2004) National policy on education ( $\left.4^{\text {th }} e d\right)$. Abuja: NERDC.

Finkelhor, D. (2008). Childhood victimization. Violence, crime andabuse in the lives of young people. Oxford University Press.

Ganai, M. Y. \& Ashraf, M. (2013). A Comparative Study of Adjustment and Academic Achievement of College Students: Journal of Educational Research and Essays 1(1),5-8.

Gaudin, M.C. (1999). The abused child and the school system. Ibadan: Royal Book Center.

Hildyard, K. L., \& Wolf, D. A. (2002). Child neglect: Developmental issues and outcomes. Child Abuse $\mathcal{E}$ Neglect, 26(6-7), 679-695.

Hopper, J. (2004). Child abuse: Statistics Research Resources. Retrieved January 25, 2014 http://www.google.com.

Ibiam, J. U. (2005). Incidence of Child Abuse in Primary School Children in Abakaliki Urban. Journal of Educational Systems Research and Development. Benin City: MONOSE Amalgamates.

Johnson, K. A. (2000). The Peer Effect on Academic Achievement among Public Elementary School Students. Heritage Foundation Center for Data Analysis. London.

Karma, C. M. M. (2009). The Relationship between Classroom Motivation and Academic Achievement in Elementary School-aged Children. Family Consumer Science Research Journal, 33(2), 106-120.

Maslow, A. H. (1943). A Theory of Human Motivation. Psychological Review, 50, 370-96.

Mills, C. (2004). Problems at home, problems at school: The effects of maltreatment in the home on children's functioning at School. An overview of recent research. London: NSPCC.

National Clearing House on Child Abuse and Neglect Information (2001). Retrieved from http://nccanch.ach.hhs.gov/pubs/factsheets/long-termconsequencies.cfm.

National Society for the Prevention of Cruelty to Children (2010). Retrieved from http:/ / www.nspcc.org.uk/inform.

National Society for the prevention of cruelty to children (NSPCC) (2010) Retrieved July 29, 2013 from http://www.nspcc.org.uk/inform.

Ngwoke, D.U. \& Eze, U.N. (2010). Developmental Psychology and Education: Theories, Issues and Trends. Enugu: Timex Enterprises.

Nworgu, B.G. (2006). Educational Research: Basic Issues and Methodology (Second and Enlarged Edition). Nsukka, Enugu: University Trust Publishers.

Obaki, S., Sang, A., \& Ogenga, P. (2013). Lessons from Mahatma Gandhi for Today's School Principals: An Instructional Model. ABC Journal Of Advanced Research, 2(2), 44-54.

Okpara J. (2001). Forms of Child abuse and Neglect practice amongst market women in Akwa South Local Government Area. (Unpublished Master's Thesis). Nnamdi Azikiwe University, Akwa.

Olaitan S. O \& Akpan, A.E. (2003). Childhood Development and Family life education. Bauchi: League of Researchers.

Out, J.E, Ushie, M.A; David, E.O., \& Ifere, A.B.E. (2011). The Impact of Child Abuse on Academic performance of youths in Calabar-South Local Government Area. African Journal of Educational and Technology 1 (2) 8-13.

Rowe, Eckenrode J. (1999). The timing of academic difficulties among maltreated and non maltreated children. Child Abuse and Neglect. 23(8) 813-832.

Royal Canadian Police (RCP) (2006). Stopping Child Abuse. Canada: Canada.

Schore, A.N. (2003). Early Relational Trauma, Disorganized Attachment, and the Development of a Predisposition to Violence. In M.F. Solomon and D.J. Siegel (Eds), Healing trauma: Attachment, mind body and brain. New York, NY: Norton.

Sidebotham, P., Biu, T., Goldsworthy, L. (2007). Child Protection Procedures in Emergency Departments Emergency Medicine Journal 24: 831-35.

Toth S. L, Cicchetti D. (1996). The impact of relatedness with mother on school functioning in maltreated children. Journal of School Psychology 34(3) 247-266.

Tsegaye, M., \& Moges, B. (2014). Roles And Challenges of Secondary School Instructional Leadership for the Achievement of Student Learning: The Case of South Gondar Administrative Zone, Amhara Region, Ethiopia. Asian Journal Of Humanity, Art And Literature, 1(1), 48-69.

U.S. Department of Health and Human Services (USDHHS) (2003). National Survey of child and adolescent well being: Baseline Report for one-year in-Foster-care sample. Retrieved May 15, 2013 from http://www.act.hhs.gov/programs/core/ongoingresearch/afc/exec-sum-nscaw/exsum-nscaw.html. 
U.S. Department of Health and Human Services Centers for Disease Control and Prevention (US.DHHSCDCP) (2010). National Center for Chronic Disease Prevention and Health Promotion Division of Adolescent and School Health. Retrieved July 29, 2013 from www.cdc.gov/HealthyYouth

Ugwu, G. C. (2007). Forms of Child Abuse and Neglect in Primary Schools in Nsukka Education Zone. An unpublished M.ed Project, Department of Educational Foundations, University of Nigeria, Nsukka.

Ukhurebor, H. E \& Nnajieto, C. C. (2005). Philosophy of Education: The foundations. Owerri: Divine Mercy.

Wambui, N. (2000). An Overview on child abuse in Kenya. ANPPCAN, Regional Office.

World Health Organization (2002). Child Abuse and Neglect in Rights of the child in Nigeria. Retrieved February 10, 2014 from http:/ / www.who.int/violence-injury-prevention.

World Health Organization (2006). Preventing child maltreatment: A guide to taking action and generating evidence. World Health Organization and International Society for Prevention of Child Abuse and Neglect. Retrieved November 16, 2013 from http:/ / whqlibdoc.who.int/publications. 